\title{
Seroma Formation in Pre-pectoral Implant-Based ADM Assisted Breast Reconstruction: A Comprehensive Review of Current Literature
}

\author{
Glenda Giorgia Caputo*, Sebastiano Mura, Roberta Albanese, Nicola Zingaretti, Camillo Parodi Pier \\ Plastic and Reconstructive Surgery Department, University Hospital of Udine, Italy
}

*Corresponding author: Glenda Giorgia Caputo, MD, PhD Plastic and Reconstructive Surgery Department, University Hospital of Udine, Italy

E-mail: sblenda@yahoo.it

IBR: Immediate Breast Reconstruction; ADMs: acellular dermal matrices; PPBR: prepectoral breast reconstruction;

\section{Rezumat \\ Formarea seroamelor după intervențiile de reconstrucție mamară pe bază de implant prepectoral cu utilizarea de ADM: un review comprehensiv de literatură}

În domeniul reconstrucției mamare pe bază de implant (implantbased breast reconstruction - IBBR), cel mai recent şi de succes progres a fost dezvoltarea abordului prepectoral prin utilizarea matricei dermice acelulare (acellular dermal matrix - ADM). Reconstrucția mamară prin intermediul ADM devine o practică standard, dar avantajele sale sunt adesea umbrite din cauza studiilor descurajante care raportează o rată crescută de formare a seroamelor. Originea acumulării serului rămâne încă neclară, dar a fost întotdeauna cea mai frecventă complicație precoce în reconstrucția mamară, dovedindu-se astfel crucial de abordat, întrucât poate duce la complicații suplimentare. Acest review are ca scop analizarea apariției seromului în chirurgia reconstructivă bazată pe implantul mamar şi posibila sa relație cu matricele, prin folosirea unei abordări standardizate pentru a obține dovezi ştiințifice de înaltă calitate. Acest review se concentrează doar pe reconstrucțiile mamare cu implanturi poziționate prepectoral la care s-a utilizat un ADM specific (Braxon), respectiv cel care are cel mai mare număr de cazuri din literatură. Interesant este că $\mathrm{ADM}$ nu par a fi cauza formării seroamelor. În schimb, se discută despre o cauză asociată intervenției chirurgicale. În acest context, a fost identificată şi analizată o serie de recomandări riguroase pentru a permite nu numai tratamentul, ci şi prevenirea seroamelor, ducând astfel la o reducere a incidenței acestei probleme frecvente.

Cuvinte cheie: reconstrucție mamară prepectorală, ADM, serom, implant, prevenire, plasă chirurgicală 


\begin{abstract}
In the field of implant-based breast reconstruction (IBBR), the most recent and successful progress has been the evolution of the prepectoral approach through the use of acellular dermal matrix (ADM). ADM-assisted breast reconstruction is now gaining a foothold as standard practice, but its advantages are often clouded due to discouraging studies reporting increased seroma formation. The origin of the serum accumulation still remains unclear, but it has always been the most frequent early complication in breast reconstruction, thus proving to be crucial to address since it can lead to further complications. Using a standardized approach to obtain high-quality scientific evidence, the aim of this review is therefore to investigate the occurrence of seroma in breast implant-based reconstructive surgery and its possible relation with matrices. We conducted the review investigating only pre-pectoral implant positioning and one specific ADM $\left(\right.$ Braxon $\left.^{\circledR}\right)$ which is the one who has the highest number of cases in literature. Interestingly, ADM does not appear to be causative of seroma formation, but a surgery-related origin is discussed. In this setting, a series of rigorous guidelines have therefore been identified and analyzed to allow not only the treatment, but also the prevention of seroma, thus leading to a reduction in the incidence of this frequent problem.
\end{abstract}

Key words: prepectoral breast reconstruction, ADM, seroma, implant, prevention, surgical mesh

\section{Introduction}

Over the past three decades, the surgical management of breast cancer has seen a significant evolution. From radical techniques, mastectomies have gradually shifted to more conservative approaches, and Immediate Breast Reconstruction (IBR) following mastectomy is now standard practice (1). Until recently, muscle sacrifice was considered an inevitable side effect of breast reconstruction. As a matter of fact, subpectoral placement of the implant was the general accepted method of implant-based reconstruction. With the development of new biomaterials such as acellular dermal matrices (ADMs), the creation of a hybrid submuscular pocket (dual plane) became possible, even without an expander, allowing for one-step procedures that have resulted in improving aesthetics and speed, with shorter operating times and reduced hospital stays $(2,3)$. Nonetheless, breast reconstructive subpectoral technique commonly leads to functional consequences. After sub-pectoral IBBR, most patients require opioids for at least 24 hours after surgery (4). In fact, subpectoral positioning not only involves frequent unnatural breast shape and capsular contracture, but above all it can cause prolonged postoperative pain with functional impairment of the upper limb due to surgical lesions of the pectoralis muscles, thus requiring physical rehabilitation $(2,5)$.

In 2012, the introduction of the new muscle-sparing technique allowed for subcutaneous positioning, thus revolutionizing breast surgery (3). The original idea of Braxon ${ }^{\circledR}$ $\mathrm{ADM}$, a new medical device constituted by a pre-shaped ADM for a complete breast implant coverage, offered the possibility to evolve from the traditional submuscular procedure to the prepectoral implant-based reconstruction (6). In prepectoral breast reconstruction (PPBR) the operative time is shortened, it is cost effective and significantly reduces pain and recovery period. According to Maruccia et al., clinical advances in PPBR with Braxon $^{\circledR}$ are ideal for making reconstruction procedures accessible even to elderly women, thus significantly improving patients' quality of life (3).

The introduction of biological matrices has therefore changed the appearance of breast reconstruction and a variety of meshes derived from either allogeneic or xenogeneic sources are now available on the market (7).

Nevertheless, despite the advantages, the literature reveals conflicting relationships with ADMs, especially in relation to post- 
operative complications. Notably, several authors have reported higher rates of seroma formation and infection (7). As a matter of fact, all breast surgeons are very familiar with seroma, defined as a collection of serous fluid that develops under the skin flaps or in the axillary dead space following mastectomy and/or axillary dissection (8). Seroma is the most common postoperative complication seen after mastectomy and axillary surgery (incidence of $3 \%$ to $85 \%$ ) and is often classified as a minor or major early complication depending on the extent. Although not lifethreatening, seromas can result in prolonged drainage which increases the risk of infections, as well as dehiscence, skin flap necrosis, and can significantly delay adjuvant therapies (8-10). Unfortunately, the pathological origin of serum formation remains unclear, although some risk factors and predictors are age, BMI, breast size, immunosuppressants, presence and number of malignant nodes in the axilla, previous surgical biopsy, and the type of surgical procedure $(8,11)$. As the complication most frequently charged to $\mathrm{ADM}$ use, seroma deserves special attention since it often causes further major complications. However, literature analysis on breast reconstruction still outlines a lack of high-quality results standardization thus highlighting the need for a homogeneous overview and comparable outcomes. In order to reduce the number of variables that could influence serum production, publications that use only the Braxon ${ }^{\circledR}$ matrix were compared, as it is the biological matrix with the highest number of scientific studies in breast reconstruction. Within the literature, this review therefore aims to analyse and elaborate the occurrence of seroma in pre-pectoral implant-based reconstruction with Braxon ${ }^{\circledR}$ - wrapped prosthesis.

\section{Materials and Methods}

To identify all relevant articles, a literature search was conducted using PubMed and Google Scholar according to Preferred Reporting Items for Systematic Reviews and Meta-Analysis (PRISMA) guidelines (Fig. 1). The keywords used for this research were "breast reconstruction" and "prepectoral" or "pre-pectoral". This research resulted in
Figure 1. Search strategy following PRISMA guidelines

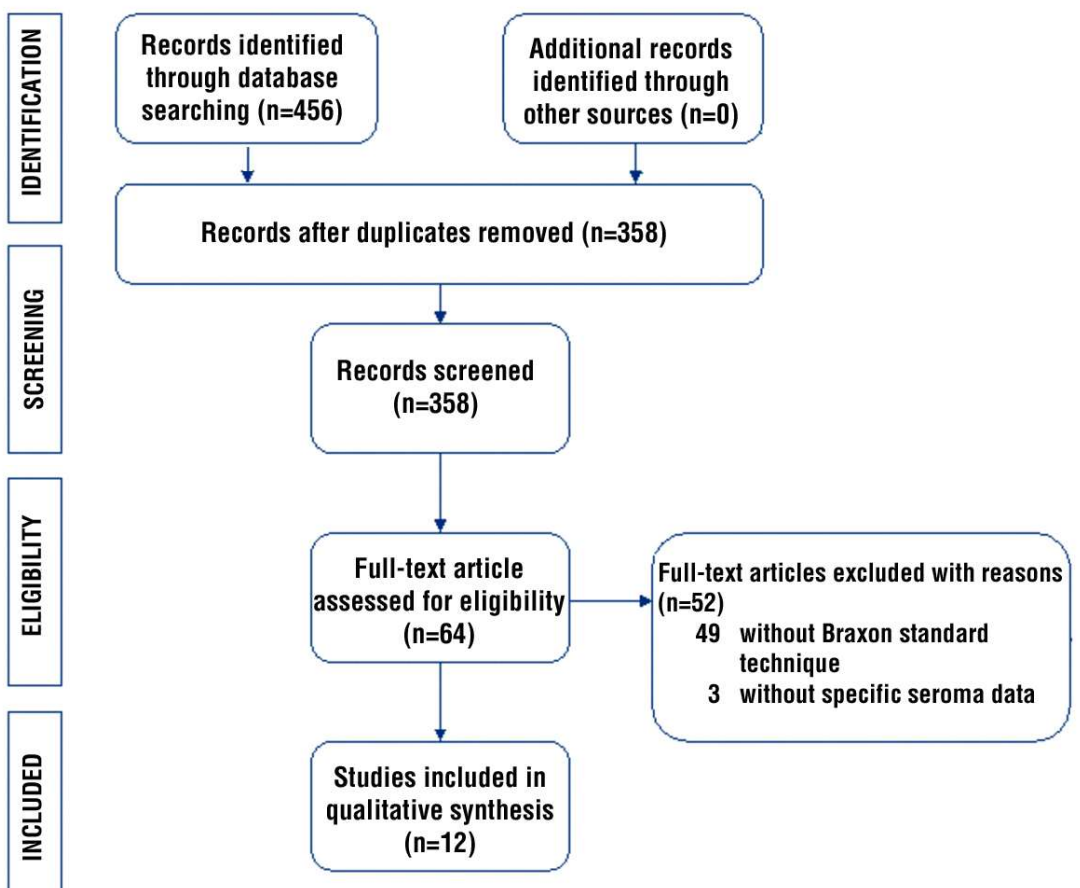


hundreds of correspondences among scientific publications, from which we have recovered the studies published in the decade from 2010 to 2019. From a preliminary screening based on the abstracts of the aforementioned studies, 64 original studies on prepectoral breast reconstructions resulted with clinical data and mean/median explicit follow-up. For the purposes of this analysis, only articles in English language were included, relating to both retrospective and prospective studies. References of the main articles found through the database search were also examined for further relevant articles. From the literature search, articles dealing with the use of different $\mathrm{ADM}$ s in breast reconstruction were found. To standardize the comparison, the $\mathrm{ADM}$ medical device with the highest number of publications was selected. Therefore, only articles using the Braxon ${ }^{\circledR}$ breast reconstruction technique were included in the review. Furthermore, the studies had to include specific data on complications found in the post-operative period. In an attempt to isolate and better focus the variables of interest, the data were collected paying particular attention to the occurrence of seroma formation in each study, underlining the percentage of implant loss. The reported seroma percentages refer to the number of implants. Only when the data were clearly indicated in each study, the results were tabulated for use in the analysis. The data were recorded and tabulated using Microsoft Excel (Microsoft Corp., Redmond, Washington).

\section{Results}

The search of the declared literature yielded 15 published articles that met the initial inclusion criteria. Three studies were removed from the analysis due to lack of data regarding seroma occurrence and treatment. All 12 articles addressed data regarding seroma formation. In most cases, these analyses were performed on retrospectively managed databases. All the studies analysed used the commercially available acellular dermal matrix Braxon ${ }^{\circledR}$ (Decomed, Venezia, Italy). The data collected on the incidence of seroma and any implant loss are shown in Table 1. The data on implant loss are not necessarily related to the serous complication but are reported as a generic index of the outcomes of the studies. The serous incidence that emerges from the collected data is quite comparable between the different studies, with the exception of Jafferbhoy S. et al. results which reports the highest occurrence of seroma.

Table 1. Studies (where Braxon was implanted) with relative number of patients, incidence of seroma and implant loss

\begin{tabular}{|c|c|c|c|c|c|}
\hline Study & $\begin{array}{c}\text { No of } \\
\text { patients }\end{array}$ & $\begin{array}{l}\text { No of } \\
\text { breasts }\end{array}$ & ADM & $\begin{array}{l}\text { Seroma } \\
\%, \mathbf{n}\end{array}$ & $\begin{array}{l}\text { Implant loss } \\
\%, \mathrm{n}\end{array}$ \\
\hline \multirow[t]{2}{*}{ Berna G et al. 2014} & 19 & 10 & $\begin{array}{l}0.9 \mathrm{~mm} \text { Braxon }^{\circledR} \\
\text { with preservatives }\end{array}$ & $12(n=2)$ & $12(n=3)$ \\
\hline & & 15 & 0.6 mm Braxon ${ }^{\circledast}$ & $12(n=2)$ & -- \\
\hline Jafferbhoy S et al. 2017 & 64 & 78 & 0.6 mm Braxon ${ }^{\circledast}$ & $23.43(n=15)$ & $10.2(n=8)$ \\
\hline Onesti MG et al. 2017 & 52 & 64 & 0.6 mm Braxon ${ }^{\circledast}$ & - & $3.1(n=2)$ \\
\hline Maruccia M et al. 2017 & 295 & 320 & $0.6 \mathrm{~mm} \mathrm{Braxon}{ }^{\circledast}$ & - & - \\
\hline $\begin{array}{l}\text { Vidya R et al. } 2017 \\
\text { (First multicenter European report) } \\
\end{array}$ & 79 & 100 & $0.6 \mathrm{~mm}$ Braxon $^{\circledast}$ & $5(n=5)$ & $2(n=2)$ \\
\hline Vidya R and Cawthorn SJ 2017 & 51 & 60 & $0.6 \mathrm{~mm} \mathrm{Braxon}{ }^{\circledR}$ & $6.7(n=4)$ & $1.7(n=1)$ \\
\hline Gardani M et al. 2018 & 42 & 51 & $0.6 \mathrm{~mm}$ Braxon $^{\circledR}$ & $3.9(n=2)$ & $3.9(n=2)$ \\
\hline Chandarana MN et al. 2018 & 61 & 71 & $0.6 \mathrm{~mm} \mathrm{Braxon}{ }^{\circledast}$ & $1.4(n=1)$ & $4.2(n=3)$ \\
\hline $\begin{array}{l}\text { Chandarana M et al. } 2019 \\
\text { (National Braxon Audit Study Group, UK) }\end{array}$ & 324 & 406 & 0.6 mm Braxon ${ }^{\circledR}$ & $7.1(n=29)$ & $6.4(n=26)$ \\
\hline Ballesio L et al. 2019 & 27 & 35 & $0.6 \mathrm{~mm} \mathrm{Braxon}{ }^{\circledast}$ & $8.6(n=3)$ & - \\
\hline Chandarana M et al. 2019 & 98 & 116 & $0.6 \mathrm{~mm} \mathrm{Braxon}{ }^{\circledast}$ & $3.4(n=4)$ & $4.3(n=5)$ \\
\hline Onesti MG et al. 2019 & 10 & 13 & $0.6 \mathrm{~mm} \mathrm{Braxon}{ }^{\circledast}$ & - & - \\
\hline
\end{tabular}




\section{Discussion}

The goal of breast reconstruction is always to use less invasive methods with even better results. After the first use of $\mathrm{ADMs}$ in breast surgery, the idea of IBBR has changed dramatically (3). ADM-assisted breast reconstruction has indeed made the evolution to the prepectoral technique possible, with the advantage of muscle sparing and reduction of the dreaded capsular contracture $(3,12)$. Prepectoral method allows a single operation with improved aesthetics and is considered the best option for obtaining a painless breast reconstruction with a faster recovery and return to daily physical activities (13). Precisely for this reason, the prepectoral approach is highly regarded by athletic women, as it ensures quick resumption of physical activity without requiring physiotherapeutic rehabilitation. Today, PPBR popularity has brought to the market several ADMs products, which differ in the production process, characteristics and different behaviours in terms of ease of handling, duration and cost. However, despite the innumerable advantages now reported by various authors, biological matrices in PPBR generally enjoy the bad reputation of being implicated in post-operative complications, particularly in seroma formation $(7,9)$. Nevertheless, seroma was a widely discussed topic even before the use of ADM in breast reconstruction, even regardless of the fact that several authors have also shown comparable results between prepectoral and subpectoral technique of implant-based IBR (14).

In 2012 Strivastava V. et al. published an interesting overview on seroma formation following breast surgery. As a matter of fact, seroma has always been the most frequent postoperative complication following mastectomy and remained a threat to both the patient and the surgeon. This complication is so common that analysis of its probable contributing factors (surgery-related, dead space obliteration, drainage, patient-factors and shoulder function) led the authors to believe that it could be a side effect of surgery itself rather than a complication (8). Given the importance and the still recurrent postoperative problem, we have analysed the present scientific evidence in order to highlight the possible causes and any advice on seroma treatment. Although the prepectoral reconstructive technique has been reported by some authors with other materials, we performed the review with only Braxon $^{\circledR} \mathrm{ADM}$, as it turned out to be the most studied adjunct device for PPBR, as well as the only ADM with a specific patented design for a standardized wrapping technique. This is the scientific rationale behind a more homogeneous review, reducing the number of variables so that data can be more easily compared across studies. Berna et al. first reported their outcomes in a series of 19 patients with 25 prepectoral reconstructions using the Braxon ${ }^{\circledR}$ technique. In their series, three patients had implant loss. Interestingly, all the major complications (chronic seroma and infection) occurred in patients with a thicker variety of Braxon $^{\circledR}$ measuring $0.9 \mathrm{~mm}$. This unsatisfactory result was related to the presence of acetone-based preservatives on this thicker membrane, which encourages inflammation and consequently fluids formation. Switching to an alternative thinner $(0.6 \mathrm{~mm})$, chemical- free, pre-shaped product seems to have addressed the high complication rate, resulting in only two minor complications (seroma) successfully treated as outpatients (3). The complete absence of chemicals inside the Braxon $^{\circledR}$ matrix was also appreciated by the total lack of red-breast syndrome in the first multicentre Europe study of Vidya R. et al, 2017 (15). These authors have reported on 100 reconstructions from different centres in Europe with an implant loss rate of $2 \%$, satisfactory cosmetic outcomes and only $5 \%$ of seroma. Two other multicentre studies are reported in the literature, concerning UK centres. Among these, the most recent by Chandarana $M$. et al (16), reports the incidence of modest complications, which fall within the general trend of the data reported in Table 1. Jafferbhoy et al, on the other hand, have reported a multicentre study on 78 reconstructions from the UK in which it 
emerges that the implant loss rate was $10 \%$, and seroma rate of about $23 \%$. The shortterm outcomes of this study are however comparable to the National Mastectomy and Reconstruction Audit (NMBRA) and the recently conducted Implant-based Breast Reconstruction evaluation audit (IBRA). This is the highest incidence of seroma reported in the use of Braxon $^{\circledR}$, as seen in Table 1 (1). Nevertheless, much higher incidences of seroma are reported in literature with the use of other surgical meshes. At the dawn of 2020, Thill $\mathrm{M}$ et al. reports a $61 \%$ incidence of seroma in their experience of PPBR with TiLOOP $^{\circledR}$ Bra Pocket (17). This is probably due to the use of a synthetic matrix that could amplify postoperative inflammatory reaction, rather than a biological matrix that establishes a tissue regenerative process (10). In fact, although the pathological origin of the seroma is not fully understood, it is likely that seromas are formed as exudate from an acute inflammatory reaction following a surgical trauma. Low levels of fibrinogen in seroma compared to plasma during the postoperative period support the hypothesis that seroma most likely originates from lymph (8). Therefore, as long as an adequate cover is used for the surgical implant (i.e., biological origin, pre-shaped and chemical-free), the literature actually reveals a poor correlation between the onset of postoperative complications and the use of ADM. This concept is reinforced by a 2015 publication, where the authors examine the amount of drainage following ADM-assisted reconstruction (Native ${ }^{\circledR}$, Decomed, Venezia, Italy) to compare it with the quantity of drainage after mastectomy without reconstruction, in order to assess whether the use of ADM increases or changes the amount of postoperative serum production and its pattern over time. Interestingly, results show that serum production peaked at 24 hours postoperatively and then rapidly declined thereafter. This trend is similar to that of the theoretical course of the acute inflammatory response, suggesting that these data support the inflammatory theory of seroma origin. Such outcomes also outline a daily serum collection trend very similar to that of mastectomy without reconstruction, thus stating that the use of ADM does not affect the drainage pattern (9). Therefore, although it is clearly not possible to eliminate the production of serum, it is essential to have a clear and comprehensive idea of its trend and all the measures that can prevent it from turning into seroma. An excellent standard for comparing the incidence of this complication is the pioneering international study Braxon Audit Group (iBAG), which has defined the largest collection of ADM-assisted PPBR patients, and which shows an incidence of seroma of $7 \%$ (12). This retrospective multicentre study collects 1450 cases of PPBR using a single standardized biological matrix, thus laying the foundation for a high-quality standard of scientific evidence. From the overall analysis of the seroma formation of the present review, the aggregate incidence of all cases examined is $4.9 \%$, an extremely good result when compared with the iBAG and the current literature (7-9). As reported in Table 1, there are studies in which no seroma formation was found at all, as in the case of Onesti et al and Maruccia et al. Through a crosscomparison of the best results obtained, a similar pattern of observations and parameters that minimize the formation of serum emerged (7-10). Generally, to prevent seroma formation, a meticulous surgical technique (carried out by experienced breast surgeons) that attenuates the postoperative inflammatory response is suggested; in addition, it is important to use a highly biocompatible and bio-active medical device such as a dry, chemical-free and not cross-linked ADM (9). Furthermore, low seroma complication rates can be attributed to a strict case selection (no major comorbidity) based on specific inclusion criteria (i.e., Braxon ${ }^{\circledR}$ ADM protocol of use) and the observation of some precautions. The first is the correct selection of the implant to reduce the dead spaces inside the pocket; for this reason, the weight of the mammary gland should be assessed after the mastectomy. Secondly, the use of closed suction drains is recommended, taking care to 
remove them at least 10 days after surgery. A crucial point then is the suture of the matrix with the subcutaneous layer which reduces the dead space and favours a more rapid integration and revascularization of the membrane. The anchorage of the wrapped breast implant to the "footprint" of the breast left in the prepectoral space after mastectomy and the subcutaneous tissue is essential to obtain intimate contact between the ADM and the living tissue in order to promote vascularization and the remodelling process. The matrix should form a snug pocket around the implant and be anchored to the subcutaneous tissue, promoting the incorporation of the matrix implant and reducing seroma formation (7). In a very recent publication by Mura S. et al., emerges that from the moment in which authors began to anchor the ADMimplant complex to both the pectoralis fascia and the subcutaneous tissue, they observed a decreasing rate of seroma as well as greater success in the restoration of breast ptosis (11). Precisely for this reason, to maintain this fundamental intimate contact, the continuous use of a support bra is recommended for the first postoperative month. This would maximize contact between living tissue and the matrix, obliterating dead spaces and promoting integration and vascularization $(7,11)$. Many seromas, then, can probably be attributed to the learning curve that accompanies the use of a new product such as acellular dermis: seroma rates decrease with increasing experience, as surgeons learn that correct intraoperative filling reduces dead space above the matrix, leading to better vascularization. From a surgeon's perspective, the muscle-sparing breast reconstruction technique with Braxon ${ }^{\circledR} \mathrm{ADM}$ had a short learning curve and reduced operating time as the creation of the ADM breast implant pocket is simple, fast, and easy to learn. Furthermore, joint work between plastic surgeons and oncologists is imperative, so that the work of one can be synergistic with that of the other (18). In fact, seroma formation is influenced by an array of surgical techniques and devices. In addition to obliteration of dead spaces and drainages, cutting tools can also promote the formation of serum. In particular, electrocautery is strongly discouraged as it is related to serum formation (8). Taken together, all these considerations present $\mathrm{ADM}$ as a safe option for women candidates for mastectomy and immediate reconstruction. Moreover, it has recently been shown that the use of ADM does not present any contraindications for postoperative radiotherapy (19). Specific studies with Braxon ${ }^{\circledR}$ have even hypothesized that this biological mesh may have a protective and therefore positive effect in treatment with post-surgery radiotherapy $(12,20)$. The treatment of any post-operative complication is in any case of primary importance, and the entire clinical process must be conducted with care and attention. It has been shown that ultrasound (US) examination can be a valid ally for a correct diagnosis of normal Braxon ${ }^{\circledR}$ matrix integration and of the possible complications (seroma included) (21). Therefore, the real winning approach in seroma prevention is a combined and synergistic strategy, which takes into account all aspects of the clinical path, from the choice of the patient, to the fundamental choice of the medical device to finish with the essential surgical measures and no demonstrations have yet been set up to confirm the role of ADM in seroma formation.

\section{Conclusion}

Prepectoral breast reconstruction with Braxon ${ }^{\circledR}$ $\mathrm{ADM}$ is an innovative muscle-sparing surgical technique that has allowed an important improvement in breast reconstructive surgery, allowing one-stage operations that ensure cost-effectiveness and a higher quality of life for patients. Nevertheless, it is now evident that a clinical and diagnostic follow-up should always be performed after surgery, in order to recognize and take action in postoperative local complications; in this setting, seroma formation and treatment is of primary importance, as it can lead to further complications. Interestingly, apart from the already known predictors of serous formation (i.e., age, BMI, breast size, comorbid conditions etc.), it 
emerges that the aetiology of serum in breast surgery is probably inflammatory and could have its roots in the surgical operation itself. As a matter of fact, the standardized analysis using Braxon $^{\circledR}$-wrapped prosthesis allowed a homogeneous overview that highlights the poor correlation between the onset of postoperative serum-related complications and the use of ADM. A set of seroma prevention guidelines outline a combination strategy as a winning approach. Apart from Braxon $^{\circledR}$ matrix, many other products are available on the market, which may differ in outcomes and complication rates, especially in the case of synthetic meshes. Further studies are needed to address this point. As for Braxon ${ }^{\circledR}$ biological matrix, results in selected cases are promising in terms of effectiveness and, compared to that reported in international literature, a low rate of seroma complications was observed. Seroma has always been a threat to both the surgeon and the patient, but meticulous surgery accompanied by selected medical devices bodes well for a successful seroma prevention and management.

\section{Conflict of Interest}

All authors declare no financial and personal relationships with other people or organization that could in- fluence this study.

\section{Ethics Approval}

Ethical approval was not needed.

\section{References}

1. Jafferbhoy $\mathrm{S}$, Chandarana M, Houlihan M, Parmeshwar R, Narayanan S, Soumian S, et al. Early multicentre experience of pre-pectoral implant based immediate breast reconstruction using Braxon®. Gland Surg. 2017;6(6): 682-8.

2. Caputo GG, Zingaretti N, Kiprianidis I, Zanfisi C, Domenici L, Parodi PC, et al. Quality of Life and Early Functional Evaluation in Direct-to-Implant Breast Reconstruction After Mastectomy: A Comparative Study BetweenPrepectoral Versus Dual-Plane Reconstruction. Clin Breast Cancer. 2020;1-8.

3. Berna G, Cawthorn SJ, Papaccio G, Balestrieri N. Evaluation of a novel breast reconstruction technique using the Braxon $\circledast$ acellular dermal matrix: a new muscle-sparing breast reconstruction. ANZ J Surg. 2017;87(6): 493-8. Epub 2014 sep 29.

4. Caputo GG, Vigato E, Rampino Cordaro E, Parodi PC, Governa M.
Comparative study of patient outcomes between direct to implant and twostage implant-based breast reconstruction after mastectomy. Journal of Plastic, Reconstructive \& Aesthetic Surgery, 2021, In press. doi: 10.1016/.j.jps.2021.03.058.

5. Cattelani L, Polotto S, Arcuri MF, Pedrazzi G, Linguadoca C, Bonati E. OneStep Prepectoral Breast Reconstruction With Dermal Matrix-Covered Implant Compared to Submuscular Implantation: Functional and Cost Evaluation. Clin Breast Cancer. 2018;18(4): e703-e711.

6. Iqbal FM, Bhatnagar A, Vidya R. Host Integration of an Acellular Dermal Matrix: Braxon Mesh in Breast Reconstruction. Clin Breast Cancer. 2016;16(6):e209-e211.

7. Vidya R, Cawthorn SJ. Muscle-sparing ADM-assisted breast reconstruction technique using complete breast implant coverage: A dual-institute UK-based experience. Breast Care. 2017;12(4): 251-4.

8. Srivastava V, Basu S, Shukla VK. Seroma formation after breast cancer surgery: What we have learned in the last two decades. J Breast Cancer. 2012;15(4):373-80

9. Caputo GG, Franchini Z, Maritan M, Pozza ED, Vigato E, Tedeschi U, et al. Daily serum collection after acellular dermal matrix-assisted breast reconstruction. Arch Plast Surg. 2015:42(3):321-6

10. Onesti MG, Maruccia M, Di Taranto G, Albano A, Soda G, Ballesio L, Scuderi N. Clinical, histological, and ultrasound follow-up of breast reconstruction with one-stage muscle-sparing "wrap" technique: A singlecenter experience. J Plast Reconstr Aesthetic Surg. 2017;70(11): 1527-1536.

11. Mura S, Caputo GG,Miotti G, Contessi Negrini F, Fin A, Rampino Cordaro E, Guarneri GF, Zanin C, D'Angelo M, Tullio A, Parodi PC. Direct-to-implant, prepectoral breast reconstruction with Braxon® dermal matrix: A singlecenter experience with 111 cases. Breast J. 2021 Feb 7.

12. Masià J, Salgarello M, Cattelani L, Parodi PC, Ribuffo D, Onesti MG, et al. The largest multicentre data collection on prepectoral breast reconstruction: The iBAG study. J Surg Oncol. 2020;122(5): 848-60.

13. Maruccia M, Di Taranto G, Onesti MG. One-stage muscle-sparing breast reconstruction in elderly patients: A new tool for retaining excellent quality of life. Breast J. 2018;24(2):180-3.

14. Chandarana MN, Jafferbhoy S, Marla S, Soumian S, Narayanan S. Acellular dermal matrix in implant-based immediate breast reconstructions: A comparison of prepectoral and subpectoral approach. Gland Surg. 2018;7(Suppl 1):S64-9.

15. Vidya R, Masià J, Cawthorn S, Berna G, Bozza F, Gardetto A, et al. Evaluation of the effectiveness of the prepectoral breast reconstruction with Braxon dermal matrix: First multicenter European report on 100 cases. Breast $\mathrm{J}$. 2017:23(6):670-6

16. Chandarana M, Harries S. Multicentre study of prepectoral breast reconstruction using acellular dermal matrix. BJS open. 2020; 4(1):71-7.

17. Thill $M$, van Haasteren $V$, Kelling $K$. Prepectoral direct to implant reconstruction following nipple sparing mastectomy using the TiLOOP bra pocket [abstract]. In: Proceedings of the 2019 San Antonio Breast Cancer Symposium; 2019 Dec 10-14; San Antonio, TX. Philadelphia (PA): AACR; Cancer Res 2020;80(4 Suppl): Abstract nr P6-14-06.

18. Sbitany $H$, Serletti JM. Acellular dermis-assisted prosthetic breast reconstruction: A systematic and critical review of efficacy and associated morbidity. PlastReconstr Surg. 2011;128(6):1162-9.

19. Apte A, Walsh M, Balaji P, Khor B, Chandrasekharan S, Chakravorty A. Single stage immediate breast reconstruction with acellular dermal matrix and implant: Defining the risks and outcomes of post-mastectomy radiotherapy. Surgeon. 2020;18(4):202-207.

20. Polotto S, Bergamini ML, Pedrazzi G, Arcuri MF, Gussago F, Cattelani L. One-step prepectoral breast reconstruction with porcine dermal matrixcovered implant: A protective technique improving the outcome in post-mastectomy radiation therapy setting. Gland Surg. 2020:9(2):219-28.

21. Ballesio L, Casinelli A, Gigli S, Boldrini C, Di Taranto G, Albano A, et al. Postsurgical Ultrasound Evaluation of Patients with Prosthesis in Acellular Dermal Matrix: Results from Monocentric Experience. Int J Surg Oncol. 2019; 2019:7437324. eCollection 2019. 